\title{
INTERNATIONAL INSOLVENCY PROCEEDINGS - DESIRED DIRECTIONS OF CHANGE AND IMPLEMENTATION
}

\author{
MAREK BIAŁKOWSKI \\ University of Szczecin, Faculty of Management and Economics of Services, POLAND \\ e-mail: marek.bialkowski@usz.edu.pl
}

RECEIVED
ACCEPTED
JEL
CLASSIFICATION

KEYWORDS

ABSTRACT

\author{
18 January 2018 \\ 2 September 2018 \\ L84
}

insolvency proceedings, debtor, creditor, claim, insolvency law

The unification of European insolvency law has been achieved via UNICITRAL model solutions, but also by way of European Parliament and Council Regulation No. 2015/848 regarding insolvency proceedings (recast version), and national legislation; in the case of Poland, this was the Law on Insolvency and Reorganisation of 28 February 2003. Insolvency law thus regulated leads to a great simplification in the application of its norms, and also contributes to their standardisation. Therefore, it should be possible to resolve insolvency proceedings in a similar way regardless of the EU member state and the legal system in operation there. Very simply, these regulations operate under the assumption that the failing debtor is operating in two or more member countries. However, in extreme cases, this kind of proceedings can also be applied when the debtor holds assets in only one of the countries in question. With such a structure there are two essentially complementary proceedings, in the form of the main foreign insolvency proceedings and secondary insolvency proceedings, and also territorial proceedings. The aim of the study is to show the mutual relations between the particular types of proceedings and arrangements, and which of them and in what order they should be carried out in order to conduct insolvency proceedings effectively. Against this background the international aspect has proved highly important, indicating that these proceedings are guaranteed for courts or bodies acting and issuing decisions, whose scope and timing play a crucial role in the selection of one of the aforementioned types of proceedings in order to effectively satisfy the creditor claiming repayment from the failing debtor.

\section{Introduction}

Going out of business, whatever its type, in some cases requires international insolvency proceedings. This applies in particular to situations in which an entrepreneur runs their main business in an EU member state, where it has its registered office and branches, or a subsidiary in the territory of one or more countries. The aim of the study 
is to indicate the need to implement a single model of bankruptcy proceedings in Poland and other EU Member States.

From a legislative point of view, issues of this kind are dealt with by international insolvency proceedings, in particular the provisions of Art. 378-417 of the Law on Insolvency and Restructuring of February 23, 2003 (hereinafter referred to as "IL"), the central issue of which is based on the regulations of the "model law" of 1997, drawn up by the United Nations Committee on International Trade Law (UNICITRAL). These issues are also covered by European law in the form of Regulation (EU) No 2015/848 of the European Parliament and of the Council of 20 May 2015 on insolvency proceedings (recast). Since, in this case, we will be dealing with legislation in the form of an EU regulation, its provisions apply directly. Therefore there is no need to enact, as in the case of EU directives, additional national statutory provisions. As a result, the provisions of the IL can only be applied in a subsidiary manner to this regulation. The opposite position could lead to a conclusion contrary to the principles of European law, in this case distorting the idea of a common legal space. And if this is the case, then the situation to which the provisions of the IL will apply in international insolvency proceedings is clear, but only in relation to those entities that do not come from an EU Member State. Consequently, the provisions of the Regulation will also not apply to insolvency proceedings initiated in the Kingdom of Denmark, which has not adopted European law in this regard. In view of the scope of international insolvency legislation, it is relatively easy to create a definition that reflects its essence.

Therefore, it can be assumed that international insolvency proceedings are those conducted against an insolvent entity which owns assets in two or more countries (Zedler, 2016, p. 247). However, since there are many variables, these proceedings can be presumed to have a special and general character. As a result, investigating the insolvent entity's assets and their location in order to initiate and conduct the proceedings with success is of enormous significance as to the consequences it brings for the subject covered by it. We are, therefore, dealing with cross-border insolvency proceedings.

In this context, the initiation of international insolvency proceedings depends on the legal system of each of the countries in which the debtor becomes insolvent. It is precisely then, according to the wording of art. 379 point 1 of the IL that foreign insolvency proceedings apply, by which we should understand legal, administrative or other proceedings subjected to foreign court supervision, the subject of which is to pursue claims against an insolvent debtor, or a debtor who is in danger of insolvency. Under this regulation, particular attention should be paid to the further wording of this definition, which indicates that insolvency proceedings may cover both property and affairs concerning the debtor that are subject to the control or management of a foreign court or a foreign administrator for their restructuring or liquidation. At the same time, the concept of foreign trustee should be interpreted in the manner provided in the regulation of the European Parliament and Council 2015/848, and thus as a person or entity whose task it is to verify and recognise the claims submitted in insolvency proceedings or to manage in whole or in part the property of which the debtor's management has been withdrawn. The Polish counterpart is the receiver [syndyk] (Gurgul, 2016, p. 800). So in this case, the legislator first of all requires the insolvent debtor to be bailed out, and only when this proves impossible, to be put into liquidation. Furthermore, such proceedings are exclusively in the jurisdiction of a foreign court, which in this case may be a court or public authority authorised to conduct or supervise foreign insolvency proceedings, as expressly mentioned in the provisions of Art. 379 point 5 of the IL.

As a rule, we can distinguish two types of international insolvency proceedings (Kłyta, 2014, p. 828). The first (the main proceedings) involves a situation in which an insolvent debtor has assets located in two different countries, 
and the proceedings may be initiated in two separate ways. This may result from a variety of legal regulations in force on their territory, where the evidence may provide a range of indications as to the scope for filing for insolvency. However, irrespective of this, after their fulfilment, a declaration of insolvency will be possible on the condition that the business headquarters or registered office are in their territory. Increasingly, however, entrepreneurs also do business outside of the country where their headquarters are located, either in the form of a subsidiary or a branch. Hence, in such cases, both main and territorial insolvency proceedings may occur. The basis for this interpretation of the main foreign insolvency proceedings is essentially the content of Art. 379 point 2 of the IL. In this case, we will be dealing with the concept of the 'debtor's main centre of interests', which in its fundamental wording corresponds to what has been previously stated. On the other hand, this issue is regulated in a slightly different way in the Regulation of the European Parliament and the Council 2015/848, which uses the terms territory, on which 'the centre of the debtor's main interests is situated' (Art. 3 Sections 1, 2 and 4 (a)). Doubts may therefore arise as to whether it would not be appropriate to apply foreign law in such circumstances. In this respect, however, the provisions of Art. 1143 of the Code of Civil Procedure (hereinafter referred to as the CCP), make it clear that the court ex officio determines and applies the provisions of foreign law, if they are indeed applicable (Pazdan, 2017, p. 113). The IL is unambiguous in this respect, giving a clear indication as to the scope of this legal regulation in the territory of the Republic of Poland.

The second type of proceedings (territorial) will apply to any other proceedings that cannot be considered as main proceedings and will also be carried out in the territory of another Member State only if the debtor has a branch in the territory of that State. The proceedings in this respect are clearly set out in Art. 3.2 of the Regulation No. 2015/848 of the European Parliament and of the Council and refer to the 'establishment' of the debtor. Furthermore, Art. 379.3 of the IL states that territorial proceedings will also apply in cases where the debtor has its place of residence or property in a country other than that where the company's head office is located (Filipiak, 2011, p. 71).

The international insolvency procedure also assumes that Member States will respect each other's legal settlements. This assumption is designed to speed up their duration, which is important in cases when an insolvent entity's assets are in separate states. In the provisions of the IL, such recognition is made by the court in the form of a decision on the recognition of foreign insolvency proceedings. This situation means that insolvency proceedings initiated earlier in another country extend also to Poland. Thanks to this legal structure, the foreign court, whose role is to liquidate the assets of the bankrupt entity, or the administrator appointed by them to manage or supervise such assets, will be also able to act effectively in Poland (Zedler, 2016, p. 249). Art. 392 of the IL clearly indicates that not only the decision on insolvency proceedings is subject to recognition, but also the announcement of its commencement. Also of note is that the basis for refusal to recognise the foreign court's decision on insolvency cannot be the premise of non-reciprocity (Gurgul, 2016, p. 810).

Since a foreign court's decision on insolvency is recognised, this may lead to negative consequences in Poland, especially if there is an intention to initiate insolvency proceedings against an entity which has already had foreign insolvency proceedings filed against it. It is thus impossible to institute such proceedings also in cases where the conditions of their initiation would be expressly provided for in the IL and the Polish court would have the power to initiate such proceedings.

However, the situation is slightly different where the main foreign insolvency proceedings are first initiated in a Polish court. In this case, it is clear that it is therefore possible to initiate secondary insolvency proceedings. This 
solution is in accordance with the model law regulations of UNICITRAL, which assumes that in the event that foreign insolvency proceedings are recognised in Poland as the main insolvency proceedings, the entity may also initiate secondary proceedings aiming at the liquidation of its property. A special feature of this type of proceedings is also that the court, when initiating secondary proceedings, is not obliged to verify whether the conditions for declaring the insolvency of the entity are fulfilled, as is the case for proceedings initiated against debtors with their headquarters and assets in Poland. This situation is clearly described in Art. 405.1(1) of the IL, which states that recognition of the initiation of foreign proceedings does not prevent the court of law from initiating insolvency proceedings. However, if the decision on initiating the main foreign insolvency proceeding has been taken, insolvency proceedings instigated in Poland are secondary insolvency proceedings. However, Art. 406.1 of the IL, in turn, establishes a different rule, although referring to secondary proceedings; namely, that secondary insolvency proceedings also apply to those insolvency proceedings initiated before recognition of the decision to open insolvency proceedings if the Polish court considers foreign insolvency proceedings to be the main procedure. It is extremely important to note that this change was made simultaneously with the recognition of the decision on the opening of foreign insolvency proceedings, due to its immediate enforceability (Gurgul, 2016, p. 821). What is significant in this case is that both domestic and European legislators have adopted a flexible formula for this kind of proceedings, giving the option to act quickly and effectively, depending on the circumstances, in order to properly and effectively secure the creditor's claims in the ongoing insolvency proceedings.

\section{Method}

This work is based on a study of the literature as well as source materials in the form of the provisions of Polish insolvency legislation along with EU Regulation No. 2015/848. In addition, in the context of international insolvency law, the regulations of the Polish Private International Law Act as well as the provisions of the Code of Civil Procedure were analysed.

\section{Results}

From the assumptions and objectives used in this work, it can be concluded that the legal solutions adopted constitute an adequate and appropriate response by legislators who, in establishing appropriate insolvency procedures, have created legal tools to ensure adequate cooperation between individual Member States in the conduct of international insolvency proceedings. In addition, it was found that the model adopted for conducting such transactions prevents double claims against the same debtor in a situation where the creditors will want to act against them. This is precisely the purpose of secondary proceedings, which is intended to balance the obligations of both parties to the proceedings.

\section{Results supply}

Creating a systemic model of insolvency proceedings not only in Poland but also in other EU Member States, and which in some situations even affects the legal regulations of countries outside of the EU, promotes economic security. 


\section{Resullts demand}

The insolvency law framework gives creditors the opportunity to effectively settle their claims, thus protecting them from dishonest debtors who, wishing to avoid the legal responsibilities of insolvency, might attempt to hide their or their own assets abroad, hoping that the existing rules would facilitate such action.

\section{Limitations}

Conducting insolvency proceedings has its limitations, regardless of the established, efficiently operating procedures that are international insolvency proceedings. A barrier to its effective implementation will be the issue of reporting claims, which assumes in Art. 54 of Regulation 2015/848 of the European Parliament and of the Council that immediately after the institution of proceedings in a Member State, each judicial authority or designated administrator is obliged to notify all creditors, including those from abroad. However, this applies only to those who are known, while others may submit their claims in any form. We should consider a limitation, which in this regard concerns the time in which they can do so. After its expiration, the claim against the debtor can not be effectively asserted.

\section{Conclusions}

The creation of an institution for international insolvency law procedure and the adoption of a new Regulation of the European Parliament and the Council No. 2015/848, replacing the existing Regulation 1346/2000 on insolvency proceedings, combined with amendments to national provisions of the Law on Insolvency, has clearly contributed to the creation of a thorough procedure for claims in insolvency proceedings, thus giving a real tool not only to creditors, but also to insolvent debtors for protecting their rights. These regulations, however, have shortcomings, such as the issue of reporting claims and deadlines before which this should be done. However, from the point of view of the principle of legal certainty, such a solution should be welcomed, since its absence could result in multiple requests for claims against the debtor. As a result, the proceedings could be extended indefinitely and this would lead to a significant increase in costs.

\section{Acknowledgments}

Sed malesuada lorem et varius sagittis. Suspendisse nisi leo, scelerisque maximus eros in, rhoncus venenatis lectus. In libero mi, consequat sit amet diam quis, gravida hendrerit ipsum. Nunc elit sem, porta ut massa at, pulvinar placerat magna. Suspendisse euismod, diam ac tincidunt luctus, massa magna vestibulum ex, at lacinia nulla sem placerat enim. Donec id ex elementum, finibus augue et, bibendum enim. Integer eget lacus pulvinar, hendrerit quam sed, porta justo. Sed hendrerit, leo sit amet venenatis rhoncus, nisl tortor ultricies orci, sed auctor tortor nulla eget purus.

\section{References}

Filipiak, P. (2011). In: F. Zedler, A. Hrycaj, P. Filipiak (eds.), Europejskie prawo upadłościowe. Komentarz. Warszawa: Wolters Kluwer Polska.

Gurgul, S. (2016). Prawo upadłościowe, Prawo restrukturyzacyjne. Komentarz. Warszawa: CH. Beck.

Kłyta, W. (2014). Provisions on international insolvency proceedings. In: A. Witosz, A.J. Witosz (eds.), Prawo upadłościowe inaprawcze. Komentarz. Warszawa: LexisNexis. 
Modelowa ustawa w sprawie upadłości transgranicznej UNICITRAL z 30.05.1997 r. Międzynarodowej Organizacji Handlu, [Model Law on Cross-Border Insolvency from May 30-th, 1997 International Trade Organization, also: Related instruments UNCITRAL Practice Guide on Cross-Border Insolvency Cooperation (2009), UNCITRAL Model Law on Cross-Border Insolvency: The Judicial Perspective UNCITRAL Legislative Guide on Insolvency Law, Part Three: Treatment of enterprise groups in insolvency (2010)].

Rozporządzenie Parlamentu Europejskiego i Rady (UE) nr 2015/848 z 20.05.2015 r. w sprawie postępowania upadłościowego (wersja przekształcona). Dz.Urz. L 141, 5.06.2015, p. 19.

Ustawa z 17.11.1964 r. Kodeks postępowania cywilnego. Dz.U. 14.06.2018, poz. 1360.

Ustawa z 28.02.2003 r. Prawo upadłościowe. Dz.U. 2017, poz. 2344 z późn. zm.

Zedler, F. (2016). Zarys prawa upadłościowego. Warszawa: Wolters Kluwer.

Cite this article aS: Białkowski, M. (2018). International insolvency proceedings - desired directions of change and implementation. European Journal of Service Management, 3 (27/2), 37-42. DOI: 10.18276/ejsm.2018.27/2-04. 